\title{
The Promise of Family Medicine: History, Leadership, and the Age of Aquarius
}

\author{
Robert B. Taylor, $M D$
}

Family medicine began as a revolutionary movement with courageous leaders who had a compelling vision for the new specialty. Next came a growth era with the expansion of residency programs, medical school departments and community practices; organizationally adept, businesslike people managed family medicine's prosperity. Today medicine and America are troubled, reminiscent of conditions in the 1960s. As family medicine enters a new era, we once again need bold, innovative leaders, like our specialty's founders. By recognizing the nature of the times and seeking the leadership we need, we can fulfill the promises we have made to our patients, our colleagues and to America.

\section{Leadership for the Future}

If I have seen further, it is by standing on the shoulders of giants.

-Isaac Newton, writing to Robert Hooke, scientist and later architect, in 1676

Who were the giants? In science, some examples were Von Leeuwenhoek who invented the microscope and first saw bacteria some 300 years ago, then Louis Pasteur, and later Alexander Fleming. Fleming's laboratory discovery led to the widespread availability of penicillin, which might have saved my grandfather's life, if it had been available when he developed an infected foot with subsequent lymphangiitis that eventually caused his

Submitted 1 July 2005; revised 4 October 2005; accepted 10 October 2005.

From the Department of Family Medicine, Oregon Health \& Science University School of Medicine, Portland, OR.

This article is an edited version of the 12 th Annual Nicholas J. Pisacano Memorial Lecture, presented 5 June 2005 at the Annual Workshop for Directors of Family Medicine Residencies held in Kansas City, MO.

Conflict of interest: none declared.

Corresponding author: Robert B. Taylor, MD, Department of Family Medicine, Oregon Health \& Science University School of Medicine, Mail Code FM, Portland, OR 972393098 (E-mail address: taylorr@ohsu.edu). death in 1930. Throughout my practice lifetime, lymphangiitis has required only a brief office visit.

In family medicine, we build on the work of general practice (GP) and family medicine (FM) giants in the United Kingdom, Canada, and the United States of America. They include rural and urban practicing physicians, educators, philosophers, medical politicians, and even a few people from other specialties who banded together to establish family medicine.

To weave a tapestry of history, leadership, and our future, I will discuss FM in 3 eras: the early years when our specialty was founded; the growth years when FM expanded in communities, medical schools, and teaching hospitals; and then the emerging era, which will determine our future. For each of these, I will look at the promises we made as well as the leadership attributes and strategies that determined how the promises were met, or not met. To do this, I will use some analogies between the history of FM and American history, including the societal context of events and some characteristics of leadership. I will propose an interpretation of the societal forces we are currently experiencing. My discussion of leadership is intended to highlight the types of persons I believe we need now and in the future, with some challenges to our emerging leaders. And later in the discussion, I will explain the allusion to the Age of Aquarius.

\section{The Early Years: 1960s through the Late 1970s}

Nicholas J. Pisacano likened the beginning of our specialty to the American Revolution. ${ }^{1} \mathrm{He}$ compared the Royalists to the old guard in medical education and the family medicine movement to the rebellious kids-the revolutionaries. ${ }^{2}$ For America, the revolution was the defining event of the $18^{\text {th }}$ century, which brought the birth of our nation. For family medicine, the early years saw the meta- 
morphosis of general practice into the specialty of family medicine, for us a seminal event.

The initial promise of family medicine was that we would rescue a fragmented health care system, put it together again, and return it to the people. Just as Henry Ford "democratized" the automobile in the early $20^{\text {th }}$ century, putting convenient transportation that was once the privilege of the few into the hands of many, family medicine held out the promise of accessible, affordable, quality health care for America. We would do this by restoring order to a muddled health care delivery system and by being inclusive, rather than exclusive, in the care provided. Early steps in this endeavor included establishing 3-year residency training programs and periodic recertification to assure quality.

\section{Societal Influences of the Times}

The future of general practice was sealed by the rise of specialization that followed WWII. "In the postwar period, the specialists had hospital privileges, rising incomes, and increasing prestige. The remaining physicians were 'just GPs' and were expected to die off (and 'good riddance')." ${ }^{3}$ The decade of the 1960s was also a time of social upheaval in areas outside medicine. Concurrent events included the Vietnam War, women's liberation and the civil rights movements. It was a time of activism that provided fertile ground for general practitioners to envision a new identity as family physicians. America, weary of disjointed and often impersonal health care, welcomed us, and federal and state governments provided financial support for residency and student training.

\section{Leadership Styles and Strategies}

For both America and for family medicine, the Early Years were the Age of Giants. The leaders of the American Revolution were the "founding fathers" we all know: George Washington, Thomas Jefferson, James Madison, John Adams and others. What were their attributes? They had been entrepreneurs, in their own way, many as farmers. They were personally powerful, daring, self-assured, and autocratic. In their hearts, they believed that they were doing the "right thing." They could envision a confederation of American states governed by Americans, and they were willing to stake their lives on their dream.

The early leaders of the FM revolution had similar attributes: Many had come from entrepre- neurial solo practices; the day of the large medical group was still ahead of us. They were self-confident, sometimes overbearing, and occasionally combative. But they were visionaries who could imagine a new specialty, they had the audacity to create a new medical specialty certifying board, and they had the passion and energy to go from town to town enlisting general practitioners to the FM cause. They knew in their hearts that family medicine was what America needed.

In residency training and medical student education we saw the rise of what I think of as the Guerrilla Residency Program Directors and the Warrior Chairs. The early program director was typically a general practitioner with a large practice that could form the nucleus of a model family practice center; these persons infiltrated the community hospitals with FM teaching programs. Eventually, residency programs which started as guerrilla campaigns often became the showcase elements of their hospitals.

In the medical schools, the battles raged. Warrior Chairs fought to gain beachheads on the campuses of academia, and some of these conflicts still simmer. At times, metaphorically, we saw blood flow in the medical school hallways, a phrase I learned from one of our early leaders, as new family medicine departments fought for hospital privileges, clinic space, and adequate funding. In some instances, early chairs left with mortal wounds, but most of the fledgling departments succeeded and began to grow.

\section{How Did We Measure Success?}

In any struggle to establish a new order of things, persistence of the new order constitutes some measure of success. As to the outcome of the American Revolution, The United States of America exists. So does the specialty of Family Medicine.

With the establishment of family medicine, society gained an infrastructure of generalist care, although we still have a long way to go in providing access to all. In community hospitals and academia, the new specialty had gained grudging acceptance, although we had yet to demonstrate the quality of family medicine clinical care.

In the early years, we counted things. We quantified our achievements by the number of "good family practice residency programs" established. ${ }^{4}$ We measured the number of students selecting careers in FM, and number of diplomates of Amer- 
ican Board of Family Practice (ABFP). By these measures we considered ourselves succeeding. And with more family physicians entering practice each year-committed to providing continuing and comprehensive care-a reasonable person would conclude that we had fulfilled our early promise: To save a patchwork health care system, make it whole, and return it to the people.

\section{Then What Changed?}

As the American Revolutionary War drew to a close, the battles ended, and the struggle to establish a unified nation began. We stopped revolting and began governing.

Family medicine was successful in becoming America's 20th medical specialty. We ceased to be counterculture revolutionaries, and we became part of the system we had come to fix.

\section{The Growth Years: Sometime in the 1970s through the 1990s}

The Growth Years in the 19th century brought America's great Westward Expansion. For family medicine, the Growth Years brought a steep rise in the number of medical school departments, the number of students entering family medicine, the number of residencies and residency positions, and the number of board-certified family physicians (FPs).

During the Growth Years, the promise of family medicine was: To return America's health care to a generalist-based model, led by family physicians who could provide quality health care for $85 \%$ to $90 \%$ of the health care needs of their patients.

\section{Societal Influences of the Time}

In the nineteenth century, America became aware of the potential of the land we inhabited, and we developed a sense of our "manifest destiny." It was a time of optimism and confidence. There were no limits to America's resources and to our future.

By the mid-1980s, family medicine was clearly succeeding: There was generous government support in the form of training grants. Battles for hospital privileges were being won. Health care cost-containment became popular, and it supported just the type of comprehensive care that we champion. In medical education, we were beneficiaries of the "generalist imperative"-with kudos to medical schools when more than half of their graduates entered generalist specialties. In fact, in the early 1990s almost every doctor wanted to be a generalist. OB-GYNs discovered body parts beyond the pelvis, and it was fashionable to be a "generalist" neurologist or ophthalmologist. Managed care made us the darlings of the health care system. We worked to have cost-efficient practices, we reveled in insurance industry support, and we learned new words such as "covered lives," "reimbursement," and "provider." But, were we aware of the subtle changes occurring in patient-physician relationships? Were we keeping our implied promise to society?

\section{Leadership Styles and Strategies}

For America and for family medicine, the era of growth became the age of administration. In the 19th century, the sons and daughters of the America's Revolution seized the opportunities for peaceful enterprise. Jefferson acquired the western United States through negotiation, without firing a shot. Once explored, the path to the West was to gain farmland and build businesses and cities. As America's early leaders were replaced, we read about presidents such as William Henry Harrison, James Tyler, James Polk, Millard Fillmore, Franklin Pierce, and James Buchanan. During the administrative years, and with few exceptions such as Abraham Lincoln and the Civil War, America was managing prosperity. We probably had just the leaders we needed for the times-levelheaded, rational, practical people with executive skills.

During our specialty's growth years, we family physicians were also managing prosperity. Our counterculture, revolutionary leaders were replaced by businessmen and women with management skills. The Guerilla Residency Program Directors and the Warrior Chairs had either changed their tactics or eased into retirement. The new residency directors understood residency curriculum design, program accreditation, and accounts receivable. The medical school chairs became experts in grant writing and educational evaluation. They all worried about budgets and personnel management. Those in charge were generally facilitative, patient, and accommodating persons. For them, peace was very important. After all, things were going very well. 


\section{How Did We Measure Success?}

Early on in the growth era, America counted new states in the union. Later we tallied miles of railroad track laid and tons of freight moved. New cities grew up along the railroad lines, and we began to be an industrialized nation.

FM learned to count value units (RVUs), covered lives, and budget surpluses or shortfalls. We tallied office visits and patients seen per hour, but with the nagging concern that cost-effectiveness might compete with quality care.

\section{Then What Changed?}

After the Civil War, America's rise continued, with only a few bumps along the way, until World War I, the Great Depression of the 1930s and then World War II. Then, in what should have been a time of prosperity, we faced economic inequities, broken promises, and leaders who had lost the trust of the people.

Family medicine's growth era ended as managed care plateaued, cost-containment faltered, and patient dissatisfaction with America's health care system rose. Government support of family medicine began to decline, and the affluence of the country became reflected in a willingness to pay more for health care-at least by those who could afford to do so. In 1998, the number of family practice residency positions filled by US medical graduates first began to fall. ${ }^{5}$ The pendulum was shifting back to sub-specialized care.

\section{The Emerging Era: from the Late 1990s and Beyond}

Today we see a continuing fascination with technology, and patients seem to value convenience over continuity. Broad-based care seems less important than "expert" care. Family physicians feel undervalued, and the specialty has lost some of its attractiveness to students-the lifeblood of our future. Residencies are currently having difficulty filling positions with US medical school graduates, and in July 2005, 39.6\% of our first year residents were international medical graduates. ${ }^{6}$

Can we characterize a new, third era at this time? Is there an analogy in American history to what we are seeing now? I considered some of the defining events of the 20th century: World War I; the Great Depression of the 1930s, which was a sobering time for America; World War II, which was a threat to all we valued; the Cold War, with the menace of nuclear annihilation; the Korean War, the Vietnam War, and recent wars in the Middle East. I thought a long time about this question, and concluded that there is no compelling analogy between a major era of American history and the current times in family medicine. Why might this be? Perhaps the reason is that we are now into a period of transition to a new era and, for both family medicine and for America, the nature of the dawning age has not declared itself. What is certain is that the character of this third era will define our future.

There is another historical transition at this time in history that I discovered while researching this paper. I found the concept intriguing, and I want to share it with you. Astrology holds that celestial bodies influence our lives as a global community. Owing to the movements of the Earth's pole visà-vis the planets, a new "age" begins approximately every 2000 years. Astrologically, we are in a time of transition-from the Age of Pisces, which began about the time of the birth of Christ, to the Age of Aquarius. As my curiosity grew, I went to the astrological web sites to learn a little about the various ages. Briefly, the Piscean Age has been characterized by spirituality and strong beliefs, sometimes causing friction among people. The Age of Aquarius will be characterized by rational science, technical progress, service, and synthesis. ${ }^{7}$ Could this be rephrased as evidence-based, electronically advanced, continuing and comprehensive care? Could we be discussing a need to reaffirm family medicine values as they relate to society's needs in the 21 st century?

Whatever happens, we are told that the transition from one age to the next will be gradual, and perhaps occasionally turbulent. And so, in this time of change, on the cusp, we are free to do some speculating.

\section{A Promise for the New Era}

The Future of Family Medicine (FFM) report clearly indicates that now is a time of change. In looking for the promise contained in the document, I conclude that it may be this: "to transform and renew the specialty of family medicine to meet the needs of people and society in a changing environment." "We are pledging to create "a new model of family medicine, a reordering of health care priorities, and a shift in the medical paradigm in the 
United States. ..." Is this not very similar to the promise family practice made in the 1960s?

During this transition time, there are headwinds and obstacles. Our residency graduates and community physicians risk the loss of influence and power in the health care system if they limit the scope of their practices, abandon hospital care, and retreat into their offices. Many family physicians find themselves, much as in the 1960s, practicing high-volume, assembly line medicine of sometimes worrisome quality.

As we seek change, we risk using a Maginot-line mentality. In the 1930s, remembering World War I, France built a line of forts on its eastern border to thwart a possible invasion by Germany. Of course, when World War II began, the fixed emplacements proved to be scant deterrent in modern warfare, and France was swiftly conquered. We cannot fight tomorrow's battle using the strategies of the last, by doing more of what worked for us in the pasttraining graduates in "model practices" that use a 1970s paradigm - just as we can neither maintain our incomes nor improve the quality of our care by seeing more and more patients, one by one, faster and faster.

In seeking to keep our promise to meet the needs of people and society, we have some assets and advantages: our patients like us, and our specialty colleagues value us. ${ }^{8}$ Our practice style can and should be user-friendly; generally, we are temperamentally altruistic and service-oriented clinicians. Ours is the most comprehensive of all health care models, representing the rational application of science. It is the synthesis of evidence, understanding, and skill. What we need is leadership to help change our practice model to adapt to today's changing environment.

\section{The Leadership Style Needed Now}

In times of crisis, strong leaders-giants-emerge. In America, Washington led us through the American Revolution, which by all military theory should have failed. Lincoln led us through the Civil War, which threatened to split the country forever. Franklin D. Roosevelt led us out of the Great Depression and through World War II.

In many FM settings today, we have facilitative managers in charge of a model that is not working well. Why do we have the leaders we have? One clue may be the differences between the generations: the Lost Generation (born during the years
1883 to 1900$)$, the so-called GI Generation (1901 to 1924), the Silent Generation (1925 to 1942), the Baby Boomers (1943 to 1960), Generation X (1961 to 1981), and the Millennial Generation (1982 and after). Family Medicine's founders, ages 50 to 65 in the 1960s and early 1970s were largely part of the GI Generation; that is, born before 1924. The GI Generation has been characterized as one of "heroes," doing great deeds and honored in myth and memory. ${ }^{9}$

Howe and Strauss conclude that if we look back as far as the 17th century, a "hero generation" arises about every 4 generations, typically following a time of upheaval in society's culture and values. They suggest that "a hero generation directly follows a youth generation widely deemed to be disappointing. . . and fills a void left by the passing of an older generation known for civic purpose and teamwork." 9

Today our senior leaders are Boomers, characterized as the "me generation," idealistic when they were young but now concerned about finances, respectful of authority, and valuing stability; they are willing to work hard and pay their dues. ${ }^{10}$ The intergenerational contrasts, clearly studies in generalities, offer some insight into our current leadership. By being cautious and seeking stability and harmony, today's leaders are missing opportunities to foment change. Nevertheless, in all of family medicine today there must be some of the visionary, risk-taking leaders-as we nuture the promise of the hero generation that I hope is coming.

\section{How Will We Measure Success?}

Our long-term goal is a new model of FM "based on the concept of a relationship-centered personal medical home, which serves as the focal point through which all persons-regardless of age, gender, race, ethnicity, or socioeconomic status-participate in health care." 8 This calls for a change in what we measure. We will assure-and document-access to care for all. We must begin to measure actual outcomes of care, such as patient diseases prevented, complications avoided, and hospitalizations and preventable deaths that do not occur. We will identify the degree to which medical decisions are based on current evidence, and provide ongoing documentation that our residency graduates are well trained and that the care provided is measurably excellent. 


\section{Challenges for Tomorrow's Leaders}

With full awareness of the recommendations of the FFM project, I believe that our successful journey through today's dangerous time of transition will call for powerful leadership in 5 areas: quality residency training and patient care, innovation, informatics, mentoring leaders, and anticipating tomorrow.

\section{Quality Residency Training and Patient Care}

To assure quality FM care, we must make some difficult decisions. Today the quality of some residency applicants and some training programs is not what it should be. During the 1990s, the leaders of anesthesiology and radiology cut training positions significantly when quality was threatened; today, a few short years later, they are increasing positions and attracting student applicants again. Now is a time when we must be leaders, acting on principle, rather than managers protecting programs that do not merit protection. We must overcome caution and close weak residencies, instead of accepting marginally qualified applicants to fill an excess of positions. To do otherwise will compromise the quality of FM care for decades.

Another approach is to extend residency training to 4 years, offering focused training to meet individual residents' needs and interests, and perhaps preparing some for future leadership roles, and others for clinical practice with a special area of excellence.

\section{Innovation}

America won the revolutionary war because we adopted a new form of warfare. Shooting at enemies from behind trees and stone walls instead of in long vulnerable ranks was an innovative tactic that allowed the colonial militia to overcome a better trained and better equipped regular army. The revolutionary family physicians created mandatory continuing medical education (CME) and required re-certification, and residency training in model family practice centers-all superb innovations at the time.

Vision plus action leads to innovation, and today we need once again to become the innovators in the health care system. We were the medical specialty that advocated family systems medicine; now our colleagues in pediatrics and internal medicine teach this to their residents. We innovated FM student interest groups; now most specialties in our medical school have copied these. Family-oriented health care, continuity clinics for trainees, community teaching practices, resident support groups-these are all things we implemented early in our history and that other specialties later adopted. But have we stopped innovating? One of the tasks of leadership is seeing possibilities and launching new ideas. What have we initiated lately that our colleagues in other specialties can eventually emulate? Today we must charge our strongest residencies and our premier medical school departments to envision the health care of the future, model these clinical innovations, and build educational programs that prepare our graduates to be ambassadors of change as they enter practice.

What might be some examples of innovation? Are we willing to take a "start with a blank slate" approach to changing residency training? Is there a better way to finance graduate medical education in FM, perhaps through the same funding mechanisms that we see with federally qualified health centers and rural health clinics? Can we think of a better practice model than we have now, perhaps one with a committed panel of patients who have subscription-based ongoing access to their "medical home?" Should we reverse the current trend of truncating our clinical services and reaffirm ourselves as, to use Whitcomb's phrase, specialists in comprehensive medicine? ${ }^{11}$ Can we think of a ground-breaking way to bring family medicine to the attention of America, so that-after almost 4 decades-our patients, communities, industry, and government come to understand who we are and what we do?

\section{Informatics}

We must lead-not merely join-the information technology transformation of health care. If we are to continue to be the leaders in offering continuing, comprehensive, and coordinated health care, then we must become the trailblazers in health information technology. The FFM report mentions the electronic health record (EHR), which should not only increase health care efficiency; it should allow us to monitor the quality of that care. We also must be the innovators in e-mail contact with patients, electronic prescribing, on-line group visits, and virtual office visits and house calls. Today the technology exists for the family physician to record a patient's blood pressure and pulse, examine the 
skin, peer into the throat, and listen to the heartall without being in the same room. Although I enjoy seeing my colleagues at medical meetings, modern information technology can allow me to maintain my $\mathrm{CME}$ without getting on an airplane or sleeping in a hotel bed. We must find groundbreaking ways to bring tomorrow's information technology into our residency training curricula, our CME programs, and our community practices today.

\section{Mentoring Leaders}

We must identify and nurture future giants. In our residencies today, there surely exist young family physicians with the qualities of integrity, courage, diplomacy, and willingness to take risks. We need to find them early and offer the leadership training and experience that can get them ready for their future roles. If this calls for extending residency training for these persons, or perhaps providing some subsidy during early practice years, then we should do this.

For now, I challenge all of us to model leadership as we speak out in hospital, local, and state forums on health issues. Be active in state and national medical organizations. And then take your medical students and residents with you to meetings to see leadership in action. Almost 30 years ago, I visited Nik Zervanos' residency program in Lancaster, PA. At that time, Nik described a program where his residency held seats on the boards of local organizations-service clubs, youth programs, and others-and these seats were occupied by his residents and then passed on to the next class following graduation. Is it any wonder that some of today's academic and community leaders have come from that residency program? And so I challenge you: What are you doing to find and mentor the giants of the future? And what are you doing to support those who wish to lead today?

\section{Anticipating Tomorrow}

Pure leaders, by definition, can see tomorrow better than the rest of us. To use a real estate analogy, they can help us "buy land in the path of progress." At this time, we need to anticipate the next change in health care in America. Some years ago I built a new house. Among my errors was my decision to have a wall cabinet to hold my 32-inch television. Of course, as televisions hypertrophied and wide screens became popular, my beautiful built-in TV cabinet turned out to be obsolete. I had failed to think ahead.

For years, I asked every expert I could find, "what comes after managed care?" The question now should be, "what is the health care model that can best serve society's needs?" Right now, by default, we have "stratified care" with about 4 or 5 levels of services, from motor scooter to Cadillac care. Where do family physicians fit in? Some may hold that we are properly the "motor scooter" doctors, but I believe that we need to be involved in quality care at all strata of America's health care system-until the system changes.

To assure our future, we need to understand our roots and our vulnerabilities. We began as a social movement to meet society's need for health care delivery. We practice "relationship-based medicine," and cannot claim exclusive ownership of an organ, age group, or specific medical technology. As such, we are vulnerable to the winds of change of America's values and social consciousness. To assure our future, we must plan for tomorrow and prepare the young family physician with the tools to do more than survive. It will be our leaders' job to see the coming opportunities for family physicians; the leaders must be, after all, the ones with the vision. To be ready, we need to increase our efforts to train leaders through workshops, seminars, and fellowships; we must seek out leaders with the temperament needed to stand up for our specialty and our values.

\section{Fulfilling Our Promise}

"What you have inherited from your fathers, earn again for yourselves, or it will not be yours" [Faust; von Goethe JW (1832)]. We are no longer managing the exuberant growth of our specialty, and there are clear parallels to the 1960 . In the postWorld War II period, the specialist had hospital privileges, rising incomes, and increasing prestige. ${ }^{3}$ Before the FM revolution, our general practice predecessors-overworked and underpaid-were dinosaurs headed for extinction.

Today family physicians are once again being tested by the specter of more work for less pay, of losing prerogatives we once took for granted, and of being marginalized in the health care system. Our task now is getting through the transition and keeping the promises we have made. In a 1790 letter to Thomas Jefferson, Abigail Adams wrote, 
"These are the hard times in which a genius would wish to live. Great necessities call forth great leaders." In today's hard times, we need visionary "great leaders" for family medicine. We need to attend to the 5 challenges of our specialty: quality, innovation, informatics, mentoring, and anticipating tomorrow. We must assure that history does not look back at family medicine as a historical curiosity that flourished at the end of the 20th century. We must once again earn the right to be America's physicians of choice.

If leadership is about any single concept, it is about change. Science, medical education, health care delivery, and the needs of society do not remain static. We, as family physicians, must be at the forefront of change. Through our leaders, we must position family medicine to show the way to tomorrow's health care. If we do so, then we may reach the age of rational science, technical advancement, service, and synthesis-our Age of Aquarius. And the promise of family medicine- - to meet the needs of people and society in a changing environmentwill be fulfilled.

\section{References}

1. Pisacano N. Quote in: Family practice: creation of a specialty. Kansas City (MO): American Academy of Family Physicians; 1980. p. 9.
2. The intellectual basis of family medicine revisited. Proceedings of the Advanced Forum in Family Medicine; 1984 September 23-28; Keystone Resort, CO. Fam Med 1985;5:225.

3. Carmichael L, Schooley S. Is where we are where we were going: a dialogue of two generations. Fam Med 2001;33:252-8.

4. Willard WR. Quoted in Wilson V. Specialist in family practice: prototype of a doctor. Gen Pract 1968;40:157.

5. American Academy of Family Physicians. Family medicine positions offered and filled with U.S. seniors, 1992-2004. Available from: http://www.aafp. org/match/graph02.html/ Accessed 2/1/2005.

6. Pugno PA, Schmittling GT, Fetter GT Jr, Kahn NB Jr. Results of the 2005 national resident matching program: family medicine. Fam Med 2005;37:55564.

7. Eile B. The age of Pisces and the age of Aquarius. Available from: http://www.astrosoftware/AquariusPicsesAge.htm. Accessed 2/1/2005.

8. Martin JC, Avant RF, Bowman MA, et al. The future of family medicine: a collaborative project of the family medicine community. Ann Fam Med 2004;2 Suppl 1:S1-32.

9. Howe N, Strauss W. Millennials rising. New York: Vintage Books, 2000; p 325-8.

10. Bickel J, Brown AJ. Generation X: implications for faculty recruitment and development in academic health centers. Acad Med 2005;80:205-10.

11. Whitcomb ME. Who's going to take care of the folks? Acad Med 2005;80:789-90. 